\title{
FROM THE CURE OF THE SIMPLE STRUCTURAL ANALYSIS TO THE CONTROL OF THE FINAL TECHNOLOGICAL QUALITY - THE CONSERVATION OF "SANTA MARIA DEGLI ANGELI" ORPHANAGE IN CASTELGRANDE (POTENZA, ITALY)
}

\author{
FRANCESCO P.R. MARINO ${ }^{1 *}$, GIANLUCA AULETTA ${ }^{1}$, FABRIZIO \\ BALDANTONI $^{1}$, FELICE C. PONZO ${ }^{1}$ AND FILIBERTO LEMBO ${ }^{1}$
}

\author{
${ }^{1}$ Università della Basilicata - School of Engineering (SI-Unibas) \\ Campus Macchia Romana, 85100 Potenza, Italy \\ e-mail: francesco.marino@unibas.it*,gianluca.auletta@tiscali.it, fbba6@hotmail.it \\ felice.ponzo@unibas.it, filiberto.lembo@unibas.it (*corresponding author)
}

Keywords: Conservation, Durability of the anti-seismic retrofits, Energy Upgrade, Quercus cerris glued laminated timber, anti-seismic timber floors

\begin{abstract}
The conservation work carried out on the "Santa Maria degli Angeli" Orphanage in Castelgrande (Potenza, Italy) following the earthquakes of 1980 and 1981 is a good example of the need to evolve and refine the concept of seismic consolidation and upgrade of monumental heritage; this, considering not only the needs of the current structural calculation, but also those related to the design of durability and overall technological quality. Built from 1878 around the original nucleus of a chapel, the seminary, then an orphanage, kindergarten, nursery school, sewing workshop and school, and summer mountain colony, constitute a precise landmark in the landscape of the ancient town of Castelgrande. Severely damaged by the earthquakes, it was declared unfit for use and evicted, and is still abandoned today. Immediately afterwards, radical refurbishment works were carried out on it, with the creation of sub-foundations, injections and tackles with reinforced concrete slabs for the load-bearing walls, replacement of the floors in steel beams and bricks with reinforced concrete floors, replacement of the wooden roofs with others of the same configuration, but in steel beams and clay tables, with a reinforced concrete slab above. The workings were not completed due to lack of funds and those performed so far show today serious pathologies (in particular the corrosion of the reinforcement of the joist of the floors and of the steel beams) as result of the lack of attention to fundamentals of materials science and of durability. Based on the current legislation and calculation methods, the research verified the seismic vulnerability of the building and proposed the necessary corrective actions: in particular, the replacement of the roofs with others, lighter and more durable, made of laminated, conditioned local Quercus cerris wood. A new destination has been proposed, linked to the presence of the Astronomical Observatory, and its upgrade to $n Z E B$ has been designed, in respect of its monumental features.
\end{abstract}




\section{METHODOLOGICAL FRAMEWORK AND RESEARCH OBJECTIVES}

The role of structural consolidation in the context of conservative restoration of heritage monuments, through discussions that spanned a period of two hundred years [1], has been enshrined in numerous Conservation Charters ${ }^{1}$, of national and international importance. Nonetheless, the debate around how to carry out these consolidation interventions is still lively, at least in Italy. On the one hand, there is he who defends the need to safeguard, above all things, the meaning of the work $[2,3]$. And, therefore, he urges the use of the same construction techniques used in the construction of historic buildings, refined over millennia of history. And he deepens, also through the Manuals of the time, the ways in which every single component was originally created by pushing himself, for example, to rediscover the use of hot beeswax to waterproof Venetian plaster [4]. On the other, the mainstream philosophy, according to which, after praising Camillo Boito and his "religious scruple" to be adopted towards monuments, every opportunity is good to fill castles, towers and churches with injected armed perforations, micro-piles and Fiber Reinforced Polymers [5]

Thus, while the Conservation Charters prescribe the conservation of the "sacrifice layers" (plasters, stuccos) and the coloring of the heritage buildings, then in reality in many Italian regions (but also in other Countries) it has become normal practice that of removing the plaster on churches, monasteries and castles to show facing stones that have never been exposed. And doing so with the approval of the Heritage Protection Bodies, and thus accelerating the degradation and / or ruin of buildings $[6,7]$. Likewise, many innovative structural solutions

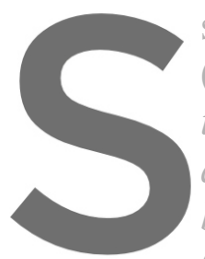
should only be allow d (according to the provisions techniques prove inadequate, any modern technique by scientific data and proved
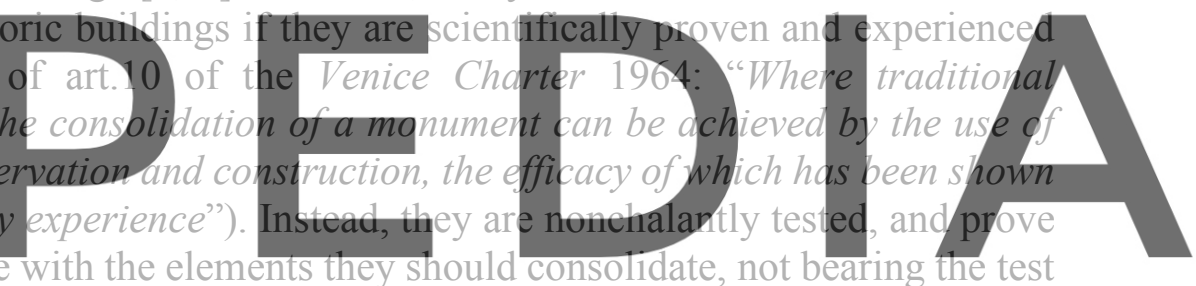

(after a few years) incompatible with the elements they should consolidate, not bearing the test of that time which the elements to be strengthened resisted. Exemplary is the risk of formation

inside walls, bonded with lime mortar. A phenomenon known since the $80 \mathrm{~s}$, but ignored by those who continued, even after (and in part continues) to inject churches, towers and casties with these products and to publish their reports, as if it were something to boast about [5]. Similarly, for the consolidation of structural elements in wood or stone with epoxy resins, whose fire resistance is almost non-existent [5].

The aim of the research was therefore to document, through a concrete case study, the effectiveness and durability of the structural recipes currently used after the 1980 and 1981 earthquakes in Campania and Basilicata for the consolidation and anti-seismic adaptation of heritage buildings, and propose the necessary modifications and implementations, as part of a general project of reuse of the heritage buildings, economically viable. The methodologies adopted are those offered by the Building Science and the Building Construction Technique,

\footnotetext{
${ }^{1}$ Ministerial Decree of 21 July 1882 and related Fiorelli Circular; Athens Charter 1930; Venice Charter 1964; Italian Restoration Charter 1972; Amsterdam Charter 1975; Charter of Conservation and Restoration of objects of art and culture 1987, proposed but never made mandatory; Washington papers 1987; Krakow 2000 and Faro 2005. And, of course, the most recent Italian standard on the matter, Legislative Decree no. 42/2004, Code of cultural heritage and landscape.
} 
the Materials Science [8] and the works of the CIB Commission W86 Building Pathology [9, 10] and of the joint Commission CIB W80 / RILEM 175-SLM Methods for service life prediction of building materials and components [11]. Commissions in which some of the Authors have participated and whose indications are already been used for a general publication on the topic [12] and for many other specific contributions on other case studies.

\section{THE "SANTA MARIA DEGLI ANGELI" ORPHANAGE IN CASTELGRANDE (POTENZA, ITALY)}

The building object of the research is one of the most relevant monuments and a precise landmark (Fig.1) of an ancient city, Castelgrande ( $40^{\circ} 46^{\prime} 00^{\prime \prime} \mathrm{N}, 15^{\circ} 25^{\prime} 00^{\prime}$ " E), on the border between Basilicata and Campania, and which owes its name to a medieval castle, unfortunately not survived earthquakes.

The Municipality now has about 900 inhabitants (decreasing) and is perched at $950 \mathrm{~m}$ a.s.1. on the crest of a hill. The building was built, starting from 1878, at the expense of individuals (the Cianci family and others) on private land, which in previous centuries (1661) housed a cemetery and a small chapel, further downstream than the current Church. The first nucleus of the complex was the easternmost part of the Church, made of brick masonry, consisting of a square-plan room (with a roof of double-pitched bent tiles supported by wooden beams, set on the walls above the transverse arches of a lowered dome) and a small entrance narthex. The building of the Rectory and then of the main building followed immediately afterwards: in 1890

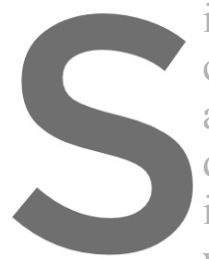
it was under construct construction of the uppe authorized, to be used destroyed in the Second identical to the first, thus
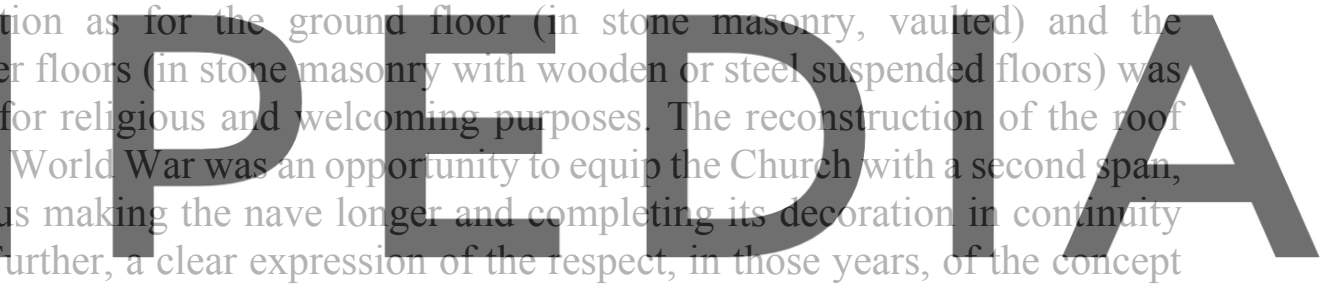
of concinnitas, as for the reconstruction of the Abbey of Montecassino, of the bridges over the

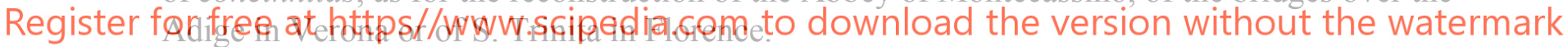

In the years between 1970 and 1980, a new building was built in the south-east end, perpendicular to the main one, raising an existing basement with two floors above ground (Fig.2). It was built with a reinforced concrete frame and placed, without seismic joints, adjacent to the main building. In this period, a house located to the west was annexed to the complex and was then raised by one floor.
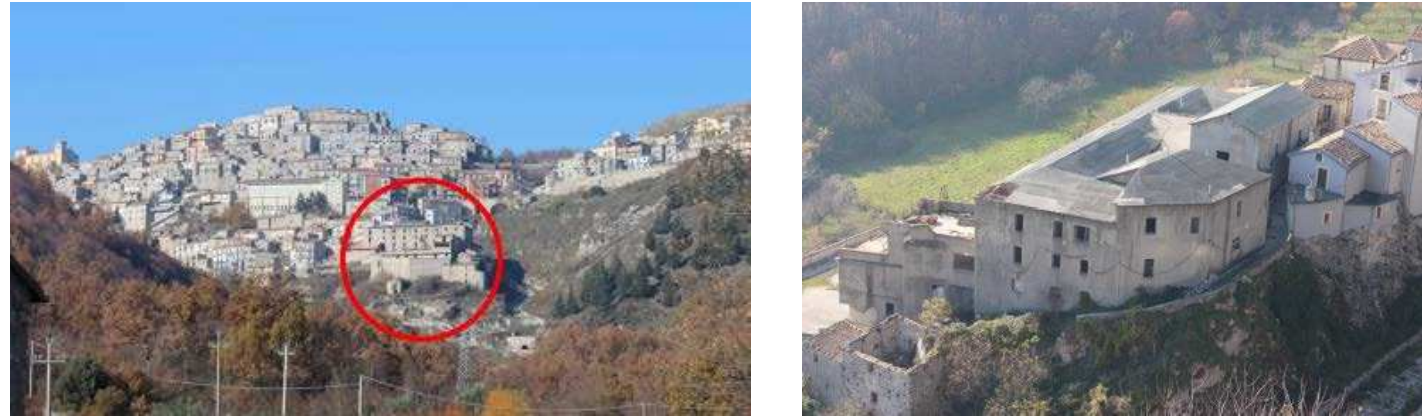

Figures 1 and 2: South panorama of Castelgrande and east view of the building object of the research 


\section{EARTHQUAKES OF 1980-81: DAMAGES AND SUBSEQUENT CONSOLIDATION INTERVENTIONS}

The earthquake of 11/23/1980 (90 seconds, 6.9 degrees on the Richter scale) and those of 1981, of less intensity, caused serious damage to the building and to the Church: the collapse of the oldest dome, the pediment and the cornice on the facade (for the hammering of the roof ridge beam); cracks on the main facade and the side walls (for disconnection of the corners and thrust of the transverse arches), with the threat of collapse due to overturning towards the outside; widespread subsidence of foundations. The damage was amplified by a series of contributing factors: the lack of regularity in the plan and in the section of the building; the eccentric position of the stairwell; the absence of bracing walls at the large rooms for dormitories and common activities; the presence of the southeast building, of a different and more deformable structure and not separated by seismic joints; the poor quality of the walls; the lack of retaining elements between floors and walls; the deformability of the floors themselves, in wood and steel; the absence of a roof slab (replaced by a simple false ceiling) and top curbs; the presence of a pushing wooden cover; the absence of effective lintels at the openings and the disordered presence of openings cut into the walls to house wardrobes, fireplaces and more.

An overall anti-seismic consolidation and recovery intervention was necessary. The design was approved by the Heritage Protection Body with the obligation of rigorous maintenance of the existing typological and structural organization, and the elimination of superfetations (the

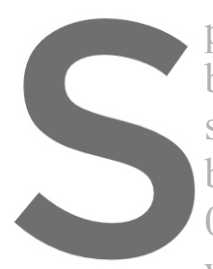
part built in the 70 s which, lowever, was ncither demolish
building through a seismic joint). The project therefore envis
sub-foundations to enlarge and stiffen the seabed of most
building, through midro-piles and reinforced concrete curbs 1
$0.60 \mathrm{~h}$, connected to each other, under the walls, every $1.5-2.0$ wall was also built, up to 10 meters high and more than $80 \mathrm{~m}$ long, to increase the external

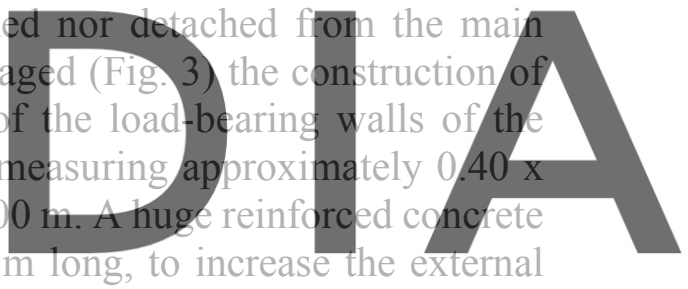

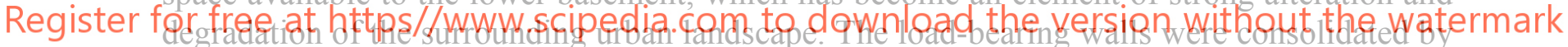

closing the openings in them, with solid brick walls, with injections of cement grout and with the application of "10 cm thick concrete slabs reinforced with welded mesh $\varnothing 820 \times 20 \mathrm{~cm}$, connected to the walls by "dovetail" couplings or simply with steel rods $\varnothing 12$ " (from the Project Report [14]). For the vaults of the ground floor, "by reinforced stitching of the same and subsequent casting on the extrados of a concrete hood with electro-welded mesh $\varnothing 820 \times 20$ $\mathrm{cm}$, effectively anchored, with metal bars, to the perimeter walls and, on the side upstream, to the rock by means of small diameter traction poles" [14].

For the floors, they were all "demolished and redone with "Bausta type" joists at a distance of $50 \mathrm{~cm}$ with interposed light brick pots and overlying r.c. slab, not less than $4 \mathrm{~cm}$ thick [14] (Fig. 4). It was foreseen that the floors of the building buried on the mountain side were tied to the rock with traction poles placed at the height of the horizontal floors, so as to block them. And that the floors were connected to the walls with curbs of a height not less than that of the floor itself, made in traces or, wherever possible, for the entire width of the walls. As for the roofs, both of the Church and of the rest of the building, the wooden ones were demolished and replaced with pitched floors made of IPE 140 steel beams every meter, clay tables and upper r.c. slab (Fig. 5). 

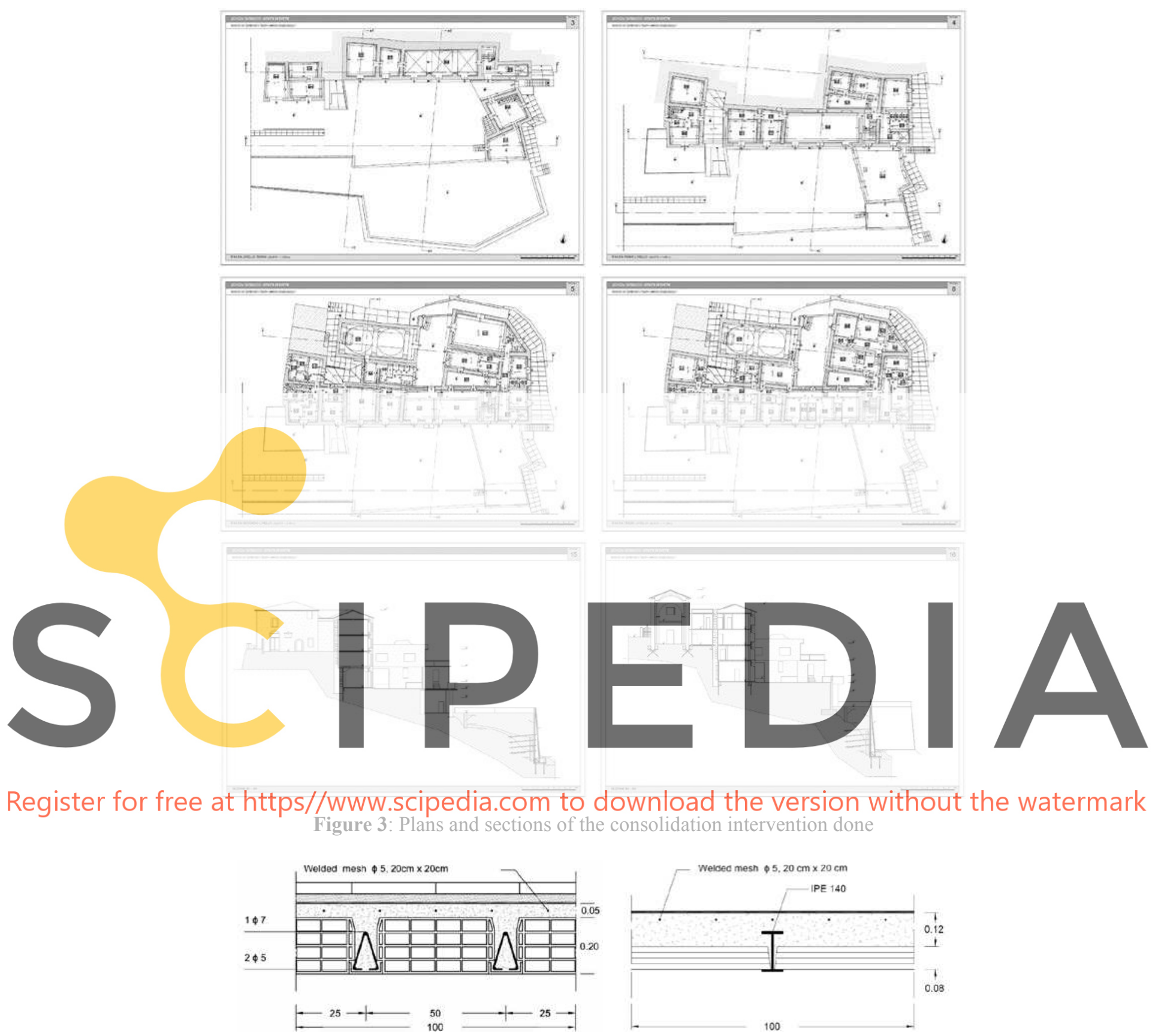

Figures 4 and 5: Details of the "Bausta type" floor (left) and of the new pitched roof that replaced the original wooden roof (right), realised in the consolidation intervention

A chain was placed on the extrados of the great central arch of the Church to harness its thrust; the corners were stitched through steel bars in concrete injected perforations. On the top of the main building, the false ceiling was replaced by a reinforced concrete floor, tied to the perimeter curb. All the lintels of the openings were reinforced by applying IPE steel beams "tear" or, when possible, by demolishing the existing arches and replacing them with reinforced concrete castings, connected to the curbs of the floors. The stairs were redone in reinforced 
concrete, redesigning them to decrease the height of the steps.

The works were carried out on several occasions and only partially, limited to most of the structural works, and the construction works aimed at the realization of the distribution scheme of an important religious, cultural and social assistance center, according to the building program for: a small seminar; a female and male orphanage with annexed laboratories; a kindergarten and an elementary school; rooms for the summer reception, such as "mountain colony", of n. 60 children. In the end, the public funding provided for by law no. 219/1981 for the reconstruction and development of the territories affected by the seismic events of November 1980 and February 1981 ended and the works were suspended, without the plants and finishing works having been carried out. The building has thus remained completely abandoned and open to the weather since the early 90s. Today the building, owned by the Municipality since 2000, is listed in the municipal list of real estate properties to be disposed of and valorized through a specific intervention plan for it.

\section{CURRENT STATE OF THE BUILDING COMIPLEX AND OBSERVATIONS ON THE EFFECTIVENESS AND DURABILITY OF THE INTERVENTIONS}

Any current recovery hypothesis of the building must start, with all evidence, from the effectiveness of the interventions carried out for the purposes of anti-seismic safety, according to current standards. Preliminarily, it must be observed how at the time the Italian legislation [14] provided for the interventions already carried out, and also provides today, that for the monumental buildings "adjustment", i.e. the sufficient to achieve an reaching the levels requi the Italian legislation do and by the client according to the po
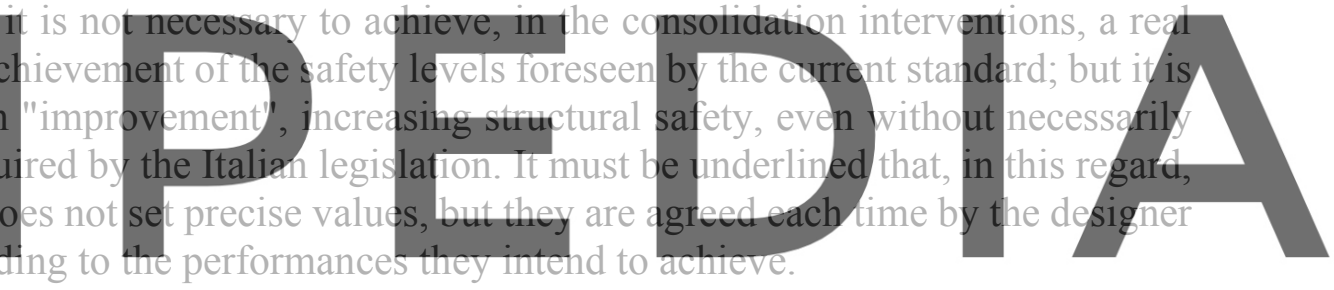

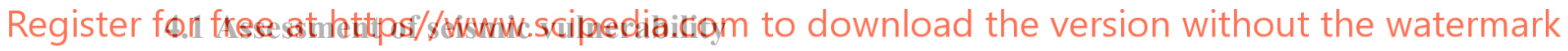

The study of the structure's seismic vulnerability was carried out by resorting to the use of nonlinear static analysis (Pushover). This choice of analysis was dictated by the fact that it lends itself better to describing the real behavior of masonry structures, unlike linear analyzes. In addition to this type of analysis, which concerns the overall behavior of the structure, local analyzes were also carried out on possible collapse kinematics. The CDmaWin software of the STS Company was chosen and used, a structural CAD aimed at masonry structures and whose calculation module uses a finite element solver [15]. The checks were carried out following the technical standards for construction NTC 2018 and considering a limited "level of knowledge", of the LC1 type, achieved, with the analyzes made on the structure of the building. From the reliefs made, they consist of two types of walls, one of disordered stone type and the other in solid bricks and lime mortar.

The demolition of the south-east building was hypothesized, because it is built in a mixed structure, in adherence to the main building, built in masonry. As foreseen in the 1986 authorization from the Heritage Protection Body, his conservation is not justifiable both for being an element of neglect of the formal apparatus of the building, and for its bad conditions of conservation, and the need to demolish it partially in every case to make seismic joints. The 
remaining part of the structural complex was divided into three parts (the Church, the main body and the basement body downstream) and modeled separately. Before performing the nonlinear static analyzes, the dynamics of these three structural bodies were studied; relative modal forms and their own periods were identified (see Fig. 6: above, the three of the Church; in the center, the three of the main building; below, the three of the basements), and the limit equilibrium analysis for local mechanisms in all the most delicate points.

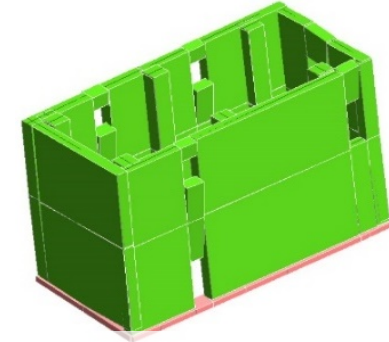

Church - first modal form Period: $0.53437 \mathrm{sec}$

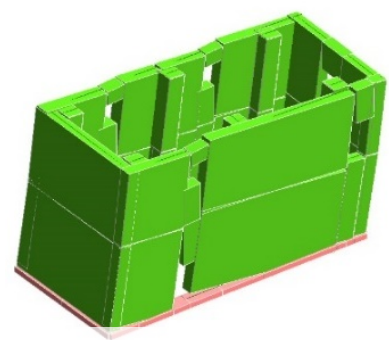

Church - second modal form Period: $0.33221 \mathrm{sec}$

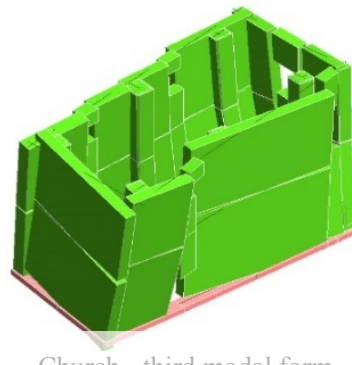

Church - third modal form Period: $0.27042 \mathrm{sec}$
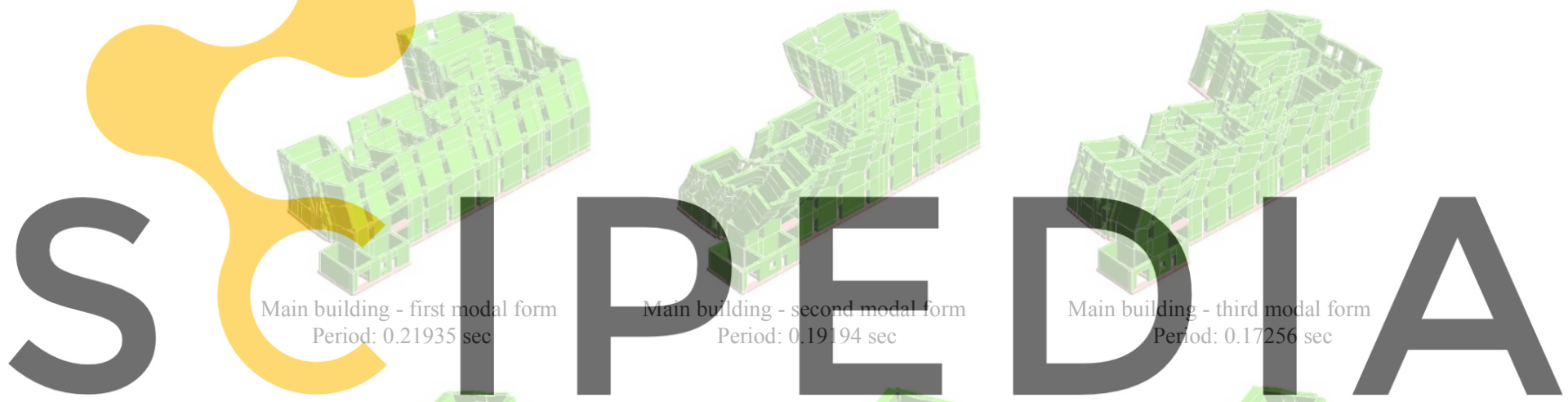

Register for free at https//www.scipedia.com to download the version without the watermark

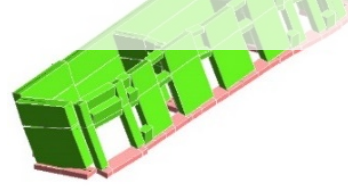

Basements - first modal form Period: $0.23261 \mathrm{sec}$

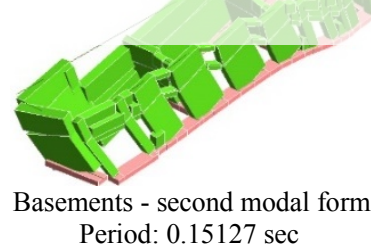

Period: $0.15127 \mathrm{sec}$

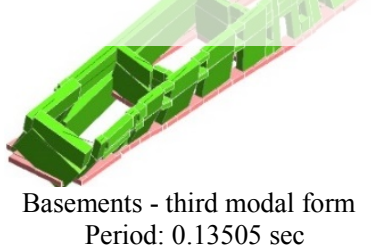

Figure 6: Modal form and periods of Church, main building and basements

After studying the dynamics and calibrating the structural models, we moved on to nonlinear analyzes (Pushover). The structural interventions already present on the building and built after the 1980 Irpinia and Basilicata earthquake were also considered in the modeling. From the study of the capacity curves, the seismic vulnerability indices relating to the three structural bodies were determined. The seismic vulnerability indices express the relationship between the acceleration of capacity of the structure and the acceleration of demand relating to the site in question. The site falls in an area with high seismic risk, the subsoil falls into the A type of the NTC 2018 (rock masses with Vs $>800 \mathrm{~m} / \mathrm{s}^{2}$ ) and the topography in the T3 type (slope with an 
inclination between 15 and 30 degrees). The PGA acceleration corresponding to the SLV (life safeguard limit) is equal to $0.31 \mathrm{~g}$, considering a nominal life of 50 years and a class of use III. The seismic vulnerability indexes are respectively 0.51 for the church, 0.55 for the main body and 0.52 for the basement: all slightly greater than 0.5 , a value which in any case can be considered acceptable for the type of destination of the structure. Therefore, the interventions carried out have raised the safety level of the entire building complex. Finally, as regards the analysis of the local mechanisms of collapse out of the plane, conducted using the limit analysis method, there were no significant critical issues, as the structures have both covering curbs and metal anchoring bars in the hammer's walls and chains in the arches of the Church.

\subsection{Interventions for improving seismic behavior and building durability}

Through the analysis, it became clear that the intervention carried out well could have been softer, more rational, and even cheaper, if he had renounced to place the two heavy floors on the top of the main building, the one above the third level and the other the sloping roof slab: they increase significantly, and in the least suitable position, the masses that undergo seismic acceleration. In relation to the conditions of severe exposure to atmospheric agents in which these elements have been found in these thirty years (with the penetration of rainwater through the badly placed bituminous membrane) (Fig. 7) both are severely corroded.
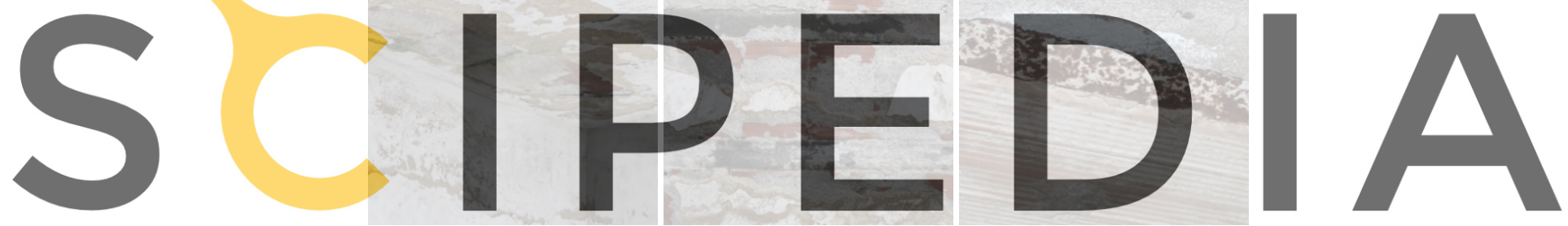

Figure 7: Accelerated degradation of structures due to the design errors illustrated in the text

Register for free at https//www.scipedia.com to download the version without the watermark On closer inspection, there are blatant design errors: the floor in Fig. 4 shows an insufficient concrete cover to ensure its durability, even if it divides internal environments [9]; and that of

Fig. 5, in the presence of IPE profiles without any protection, is destined to corrode quickly by differential aeration [9]. The same mistake was repeated for the roofing of the Church, where the heavy roof was built, when light wooden trusses could have been chosen. It is therefore appropriate to remove these heavy floors, leaving only the perimeter curbs in place, which would otherwise be problematic to remove without destroying the upper cornices of the buildings, subject to a specific protection rule. Light reticular wooden trusses can be placed in their place. In this regard, the Authors have devised and developed [16][17][18] a particular thermo-hygrometric conditioning method for a species of hardwood widespread in Basilicata, the Quercus cerris (Turkish Oak), which allows the production of laminated wood beams with exceptional static performances [17] (Fig. 8). In this regard, even if the latest Standard UNI EN 14080:2013 only reports strength classes from GL 20h to GL 32h, remark that the reference to the resistance class GL 36h "refers to laminated wood obtained from specific hardwood species based on some provisions of the current European standard" and following the results of the tests carried out on the Quercus Cerris laminated wood specimens typed as a number and size of the lamellas and glue used [16]. 


\begin{tabular}{|c|c|c|c|c|c|c|c|}
\hline \multicolumn{3}{|c|}{ Class of resistance } & \multirow{2}{*}{$\begin{array}{c}\text { GL } 24 \mathrm{~h} \\
24 \\
\end{array}$} & \multirow{2}{*}{$\begin{array}{c}\text { GL } 28 \mathrm{~h} \\
28\end{array}$} & \multirow{2}{*}{$\begin{array}{c}\text { GL 32h } \\
32\end{array}$} & \multirow{2}{*}{$\begin{array}{c}\text { GL } 36 \mathrm{~h} \\
36 \\
\end{array}$} & \multirow{2}{*}{$\begin{array}{c}\text { Quercus } \\
\text { Cerris } \\
102.2 \\
\end{array}$} \\
\hline $\begin{array}{l}\text { Flection's characteristic } \\
\text { resistance }\end{array}$ & fung & $\mathrm{N} / \mathrm{mm}^{2}$ & & & & & \\
\hline $\begin{array}{l}\text { Parallel traction's } \\
\text { characteristic resistance }\end{array}$ & feog: & ${\mathrm{N} / \mathrm{mm}^{2}}^{2}$ & 16.5 & 19.5 & 22.5 & 26 & 94.17 \\
\hline $\begin{array}{l}\text { Perpendicular traction's } \\
\text { characteristic resistance }\end{array}$ & $f_{\text {sopex }}$ & $\mathrm{N} / \mathrm{mm}^{2}$ & 0.40 & 0.45 & 0.50 & 0.60 & 2.09 \\
\hline $\begin{array}{l}\text { Parallel compression's } \\
\text { characteristic resistance }\end{array}$ & fasese & $\mathrm{N} / \mathrm{mm}^{2}$ & 24 & 26.5 & 29 & 31 & 89.53 \\
\hline $\begin{array}{l}\text { Perpendicular compression's } \\
\text { characteristic resistance }\end{array}$ & fospex & $\mathrm{N} / \mathrm{mm}^{2}$ & 2.7 & 3.0 & 3.3 & 3.6 & 9.94 \\
\hline $\begin{array}{l}\text { Cutting's characteristic } \\
\text { resistance }\end{array}$ & foer & $\mathrm{N} / \mathrm{mm}^{2}$ & 2.7 & 3.2 & 3.8 & 4.3 & 9.64 \\
\hline Mean parallel elastic modulus & Eogme & ${\mathrm{N} / \mathrm{mm}^{2}}^{2}$ & 11600 & 12600 & 13700 & 14700 & 23413 \\
\hline $\begin{array}{l}\text { Parallel elastic modulus sth } \\
\text { percentile }\end{array}$ & $E_{\text {eges }}$ & $\mathrm{N} / \mathrm{mm}^{2}$ & 9400 & 10200 & 11100 & 11900 & 18953 \\
\hline $\begin{array}{l}\text { Mean peppendicular elastic } \\
\text { modulus }\end{array}$ & $\begin{array}{l}\text { Expen } \\
\text { ser }\end{array}$ & ${\mathrm{N} / \mathrm{mm}^{2}}^{2}$ & 390 & 420 & 460 & 490 & 780 \\
\hline Modulus of sliding & $\mathrm{G}_{\mathrm{n} \text { man }}$ & $\mathrm{N} / \mathrm{mm}^{2}$ & 720 & 780 & 850 & 910 & 1460 \\
\hline Mean density & $\mathrm{r}_{2 \mathrm{k}}$ & $\mathrm{kg} / \mathrm{m}^{3}$ & 380 & 410 & 430 & 450 & 815.77 \\
\hline
\end{tabular}

Figure 8: Performances of the elements developed by the Authors [16] [17], in laminated wood of Quercus cerris thermo-hygrometrically conditioned

The relative pitched floor is provided in the same wood, insulated and ventilated and covered with double-ro of tiles as well as the original one (see below, Fig. 10). Other interventions are necessary to drain the surface waters at the boundary and under the buildings and limit the phenomena of capillary rise, favoring the evaporation of the water contained in the ground through cavities and floors permeable to steam (see below, Fig. 11).

\section{THE REHABILITATION AND REFURBISHMENT HYPOTHESIS}

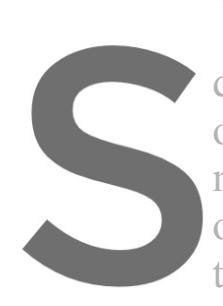

In "Toppo di Castelgrande"

due to the absence o observatories has been bui many other related equipment, observatory for amateu telescope $(\varnothing 40 \mathrm{~cm})$, wh
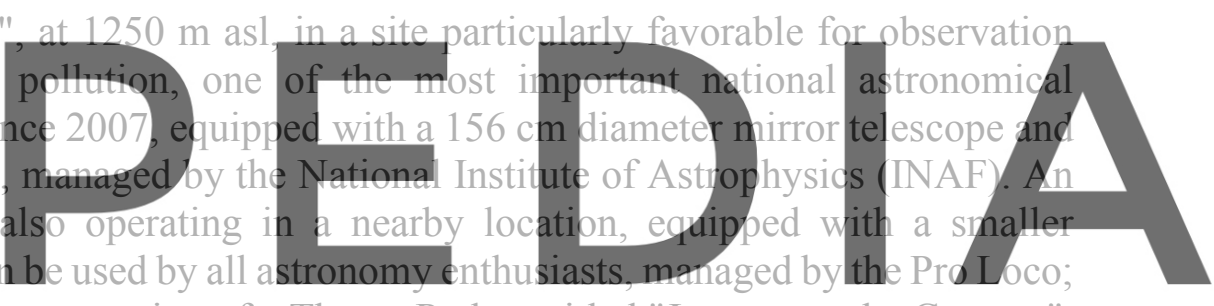
and work is underway for the construction of a Theme Park, entitled "Journey to the Cosmos",

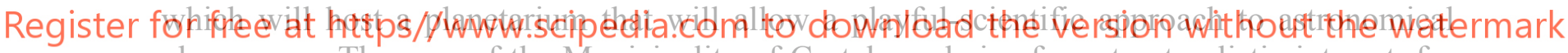
phenomena. The area of the Municipality of Castelgrande is of great naturalistic interest, for the richness of its chestnut and broad-leaved forests in general, for birdlife and for the intact landscape. We have therefore studied the methods by which to develop religious and welfare hospitality (the reason why the building complex was built), towards the hospitality of the international scientific community and naturalist tourists.

And this with the creation of an "Astronomical Study Center", divided into offices, study rooms, meeting and conference rooms and a library, in addition to the dining area and the hotel. On the first basement floor there would be the main parking lot, deposits and rooms for thermal and electric power plants and systems. It would be connected by a ramp on the ground level (Fig. 9a, top left), which would house the parking for the handicapped, pantry and cellar, kitchen, restaurant in the room covered with cross vaults, the staircase and the elevator for the access to the upper floors. An external walkway, which passes under an arch, connects this level with the higher ones, up to the square around the former church. At the first level (Fig. $9 \mathrm{~b}$, top right) would be located: the hotel reception, the internet point, offices and meeting room, toilets, stairs and lift. At the second level (Fig. 9c, bottom left) they would find n. 7 hotel rooms, for $n .13$ beds; the library in the former church, with related services; the conference room and its offices and services; stairs and lift. At the third level they would find n. 9 hotel rooms and 
one suite, for $n .20$ beds and two storage rooms (Fig. 9d, bottom right).

\subsection{The thermal upgrade in nZEB}

As a result of the Directive 2010/31/EU of the European Parliament and of the Council on the energy performance of buildings, after 31 December 2018 buildings occupied and owned by public authorities, on which 'major renovation' is done, must be 'nearly Zero Energy Buildings' (nZEB). That "means a building that has a very high energy performance...The nearly zero or very low amount of energy required should be covered to a very significant extent by energy from renewable sources, including energy from renewable sources produced on-site or nearby" (Article 2, Definitions, of the Directive). The challenge that arises today, when working on cultural heritage buildings, is to reconcile the theories on conservation $[1,2,3]$ and the new needs for energy efficiency refurbishment, but not only [7, 19].

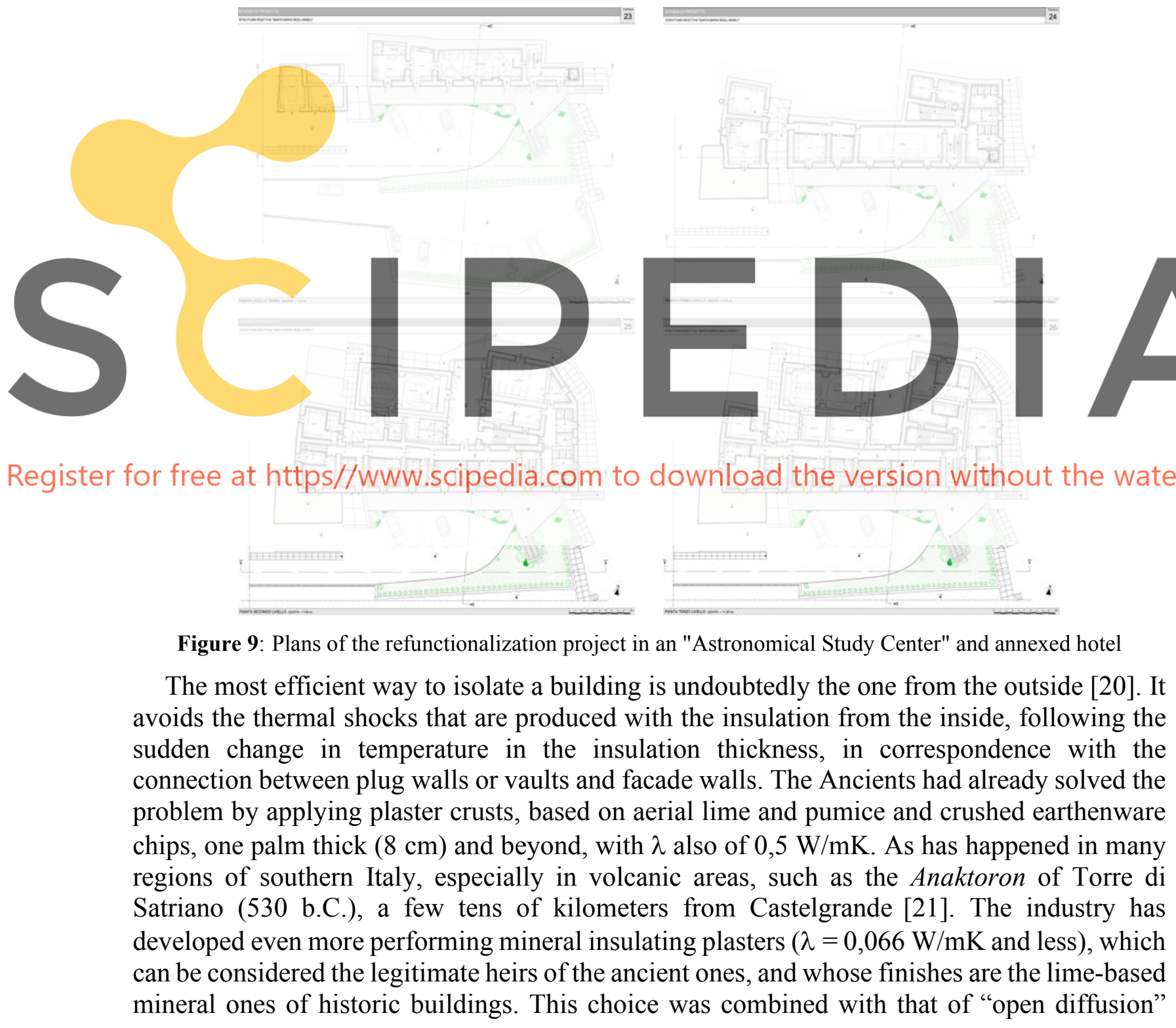


insulation from the inside, in expanded perlite $(\lambda=0,045 \mathrm{~W} / \mathrm{mK})$, which is aimed at minimizing energy consumption and contributing decisively to transforming the building in an nZEB. With limestone walls $60 \mathrm{~cm}$ thick, plated with the existing reinforced concrete counter-wall, $15 \mathrm{~cm}$ thick, the current transmittance is $U=1.93 \mathrm{~W} / \mathrm{m}^{2} \mathrm{~K}$. By adding $10 \mathrm{~cm}$ of insulating plaster on the outside and $8 \mathrm{~cm}$ of expanded perlite on the inside, the transmittance after the hypothesized intervention becomes $U=0.265 \mathrm{~W} / \mathrm{m}^{2} \mathrm{~K}$ (Fig. 10). Cornices and stone windowsills are safeguarded, dismantled and reassembled ten centimeters further out, in order to maintain the same previous ratio with the plane of the walls, connecting them with stainless steel shelves for balconies, like Halfen type. The ground connection of the heated rooms is assumed to be drained, insulated and ventilated through the internal environment (Fig.11) in order to be dehumidified. Its transmittance, which is now $U=3.549 \mathrm{~W} / \mathrm{m}^{2} \mathrm{~K}$, would become $\mathrm{U}=0.208$ $\mathrm{W} / \mathrm{m}^{2} \mathrm{~K}$. The whole building is assumed to be equipped with Controlled Mechanical Ventilation systems divided by zones and equipped with dehumidification batteries, since the average relative humidity of the external environment only in July and August drops below $60 \%$, and for the rest of the year is much higher, reaching an average of $80 \%$ in the winter months. These systems would also dissipate the moisture transmitted by the soil through the ventilated cavities and the wall or floor coverings. The roof, which currently has a transmittance $U=2,723$ $\mathrm{W} / \mathrm{m}^{2} \mathrm{~K}$, with the new package, insulated with $20 \mathrm{~cm}$ of wood wool and ventilated, would assume a $\mathrm{U}=0.176 \mathrm{~W} / \mathrm{m}^{2} \mathrm{~K}$. Photovoltaic tiles substantially indistinguishable from the traditional ones are expected to be placed on the roof slopes correctly oriented to South, for a surface equal to $327.5 \mathrm{~m}^{2}$, with the possibility of producing $20 \mathrm{kWp}$. Passive house wooden frames have been hypothesized, with $\mathrm{U}_{\mathrm{w}}=0,82 \mathrm{~W} / \mathrm{m}^{2} \mathrm{~K}$.
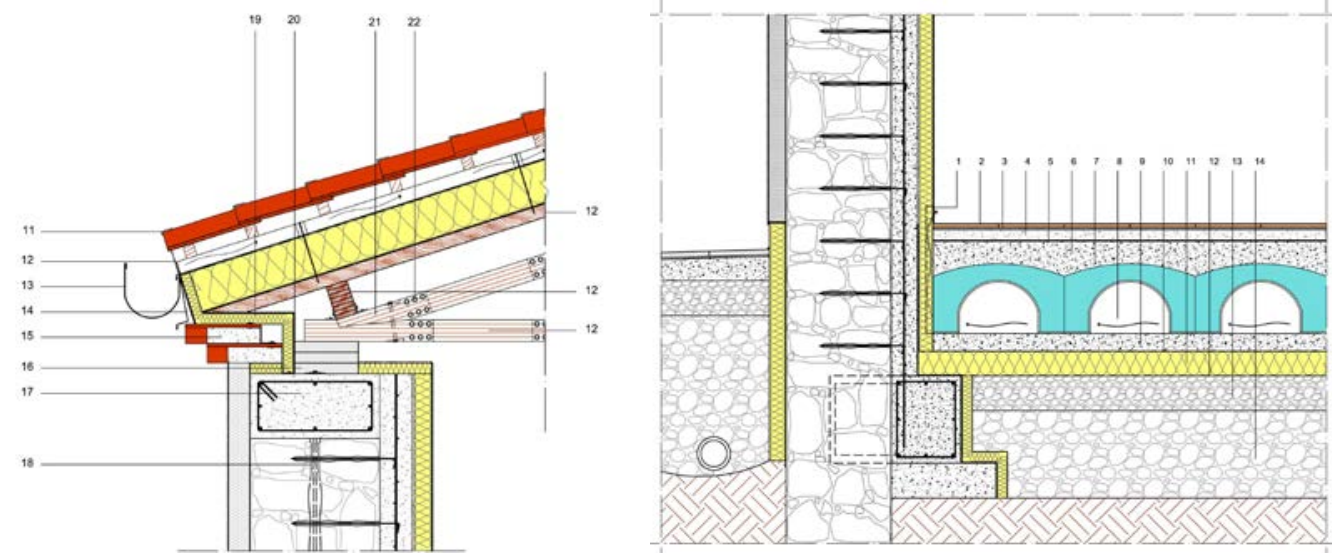

Figures 10 and 11: Details of the vertical closure-cover node (left) and the ground connection (right)

At present, the building if it still had the original fixtures and heating system, would have a very bad energy classification, in Class $\mathrm{G}$, the worst, with a primary energy index for heating and domestic hot water EPi $+\mathrm{EPacs}=696.8 \mathrm{kWh} / \mathrm{m}^{2}$ year. Following the planned changes, it would go into Class A4 with EPi + EPacs $=24.7 \mathrm{kWh} / \mathrm{m}^{2}$ year, 28 times lower, and would be fully classified as nZEB. Thanks to the insulation from the outside, it would have a great useful thermal inertia, which would allow it to face the summer seasons without air conditioning systems.

\subsection{Lighting and acoustic upgrade}


A meticulous study was conducted on the quantity and quality of lighting provided by the existing windows, in relation to the intended destinations, through the study of the Average Daylight Factor (FLDm), referred to by the relevant national regulations (in particular UNI EN 12464-1), and experimental tests were carried out using a Delta OHM luxmeter mod. 4D8501. This has resulted in valuable indications regarding the need in many rooms to integrate existing windows by means of reflective blinds inside the frame and reflective ceilings, translucent overdoors for corridors, Solar tubes and Solar Spots, so as to reduce as much as possible the use of artificial lighting of the rooms. Given the large mass of the wall elements and the high acoustic efficiency of the external fixtures, in a space with little external noise, the attention from the acoustic point of view has turned to the insulation from internal noises, from trampling and from plant and machinery, and to control the reverberation times of the largest and most common rooms. Light multi-layer walls have been provided with internal rock wool insulation, with high and proven efficiency in reducing airborne noise, and heavy doors equipped with effective seals; absorbent floors and screeds on resilient layers with low dynamic rigidity to reduce impact sounds. The widespread use of sound-absorbing plasters with $\alpha$-Sabine 0.8 and, where necessary (former Church, restaurant, meeting rooms), suspended ceilings with specific characteristics and acoustic performance has been envisaged.

\subsection{Sewing of the injury constituted by the large wall against ground}

The need to reconstruct the relationship of the building with its environment, altered by the construction of the large wall against the ground downstream, has led to the proposal to create a natural cladding creeper (Hedera helix, Hedera Hibernica, Trachelospermum jasminoides) on a cable network and a layer of non-woven fabric fixed to the wall.

\subsection{Color and surface texture}

As said, the characteristic color of the building (except the stone frames or the "romanelle" of the upper cornice, destined to remain unchanged) has always been white. There are at least 300 whites, and each of them may appear whiter or grayer, depending on the texture with which it is spread (smooth, with a more or less fine grain size, applied with a float or trowel, with parallel movements or crossed, orange peel or scratched, and so on almost endlessly). The proposed restoration of the original appearance of the building foresees the use of only the white color on the outside, available in two versions: perfectly smooth, and therefore lighter, for the architectural elements (pilasters, cornices), present above all on the external surface of the former church; trowel treated, with a grain size of 2-3 mm, with crossed movements, and therefore more full-bodied and slightly more gray, due to the fields between the architectural elements and the facades of the main building. Just as, moreover, it results from the historical photographic documentation.

\section{CONCLUSIONS}

The anti-seismic consolidation interventions generally carried out in the 80s-90s of the last century have very often privileged the aspect of pure calculation, rather than considering the technological correctness and durability of the works.

And, the works that involved "Santa Maria degli Angeli" Orphanage of Castelgrande, which are a good example of this way of operating, have not escaped this logic. Thirty years later, the 
result is buildings that meet current anti-seismic standards but on which it is necessary to intervene heavily, to ensure its conservation. A vision, at the same time more complex and more precise, extended to the consideration of the relationship with the ground in the different points of the building, of the waterways, of the individual injuries and of the individual subsidence, would probably have allowed to operate in a "lighter" way. Without a single recipe for all parts of the building, but certainly saving resources to use them in the drainage and hydraulic arrangement of the area. The choice to build the downstream wall and the two roofs was undoubtedly useless and harmful, and burned resources that could have been more usefully used to complete or at least cover perfectly and close the building.

More and more, the design tasks ask designers for an overall strategic vision, within which to implement the most appropriate tactics, to be evaluated in cross-comparisons, through which to decide the best one. The search for sustainability pushes to invest in the quality of the solutions and in their durability. It is no longer admissible for a designer to decide on a concrete cover or the technique of using a steel section without asking the question of the durability inherent in the solution.

Authors' contribution. F Lembo coordinated and provided the research objectives. FPR Marino has developed the various aspects of research, the methodological and operational tools and verified the accuracy of research results. G Auletta and FC Ponzo studied the structural aspects and the assessment of seismic vulnerability. F Baldantoni made specific analyzes in his graduation thesis. The authors' contribution in manuscript revision, editing and writing the text of the paper, was the same.

\section{REFERENCES}

[1] Marconi, P. Il restauro e l'architetto. Teoria e pratica in due secoli di dibattito. Marsilio, Venezia (1988), ISBN 88-317-5759-8.

[2] Marconi, P. Materia e Significato. La questione del restauro architettonico. Gius. Laterza \& Figli, Roma-Bari (1999), ISBN 88-420-5851-3.

[3] Marconi, P., Il recupero della bellezza. Skira, Milano (2005), ISBN 88-7624-484-0.

[4] Scappin, L. Il saper fare gli intonaci "par modo che li stiano bene", dalle fonti scritte alle sperimentazioni. In F. Doglioni et al. (Eds.): Conoscenza e restauro degli intonaci e delle superfici murarie esterne di Venezia: campionature, esemplificazioni, indirizzi di intervento, Il Prato, Venezia (2017), pp. 374-423, ISBN-10 8863364036.

[5] AA.VV. Trattato sul consolidamento. Mancosu editore, Roma (2003), ISBN 88-87017-069.

[6] Giebeler, G., Krause, H. and Fisch, L. Refurbishment Manual. Maintenance, Conversions, Extensions. Basel Birkhäuser Architecture, Detail Construction Manuals, Munich Edition (2009), pp. 208-209 e 210-213.

[7] Lembo, F. Difendere e diffondere la cultura degli "strati di sacrificio" e del colore dell'edilizia storica. In: Convegno Architetti e Restauratori dei Beni Culturali, Trento, Italy, 7-8 novembre (2019, in press).

[8] Offenstein, F. Compatibles, incompatibles - ou comment associer les matériaux de construction, Editions du Moniteur, Paris (1988).

[9] CIB W 086 Publication 155, 1993. Building Pathology, A State-of-the-Art Report. Rotterdam, The Netherlands: CIB Press, 78 p. 
[10] CIB W 086 Publication 393, 2013. A State-of-the-Art Report on Building Pathology. De Freitas V.P. (edited by). Rotterdam, The Netherlands: CIB Press, 200 p. ISBN 978-906363-082-9.

[11] Lacasse, M.A. and Sjostrom, C. Methods for service life prediction of building materials and components - recent activities of the CIB W80/RILEM 187-SLM. In: Proceedings of the International Workshop on Management of Durability in the Building Process, Milan, Italy (2003), June 25-26, pp. 1-11.

[12] Lembo, F. and Marino, F.P.R. Il comportamento nel tempo degli edifici. Cause di degrado e soluzioni progettuali dei sistemi edilizi "tradizionali" ed "industrializzati". Casi di studio. EPC Libri, Rome, Italy (2002), ISBN: 88-8184-241-6, con ampia bibliografia.

[13] Martone, A. Relazione al progetto di riparazione antisismica della Casa delle Figlie di Maria Ausiliatrice Salesiane di Don Bosco, Castelgrande (1986), presso l'Ufficio Tecnico del Comune di Castelgrande.

[14] D. Lgs. 22 gennaio 2004, n. 42 Codice dei beni culturali e del paesaggio, art. 29, $4^{\circ}$ co. e D. M. 17 gennaio 2018 Aggiornamento delle "Norme tecniche per le costruzioni". In: Supplemento ordinario alla Gazzetta Ufficiale n. 42 del 20 febbraio 2018, punto 8.4.2 "Intervento di miglioramento", pag. 292.

[15] S.T.S. Software Tecnico Scientifico. CDMa Win: Computer Design of Masonries, software per la verifica di strutture in muratura. Siracusa, Italia (2018).

[16] F.P.R. Marino, F. Lembo, A. Videtta, C. La Notte. Quercus Cerris glued laminated timber: a novel material derived from wood. Tests on thermoigrometric conditioning, wood adhesives and flexion breakout tension. In: Sustainable Housing Design Emphasizing Urban Housing - XXXIV IAHS World Congress, Luciano Editore, Napoli, Italia (2006), Settembre 20-23. ISBN: 9788860260307. http://hdl.handle.net/11563/11205

[17] Lembo, F. and Marino F.P.R. Floors realized in Quercus Cerris laminated timber in buildings with structure in masonry, performing anti-seismic functions. In: B.P. Sinha and L. Tanaçan (Eds.): Proceedings of $8^{\text {th }}$ International Seminar on Structural Masonry, Çizgi Basim Yayin Ltd. Sti, Istanbul, Turkey (2008), November 05-07, pp. 441-448. ISBN: 9789755613420. http://hdl.handle.net/11563/11203

[18] Lembo F, Marino FPR, Masullo R. Anti-seismic light, ductile, sustainable and reversible timber Quercus Cerris floors for reinforcement in conservation design. In: Branco JM, Poletti E, and Sousa HS (Eds.): Proceedings of 5th International Conference on Structural Health Assessment of Timber Structures - SHATiS'2019, Universidade do Minho, Escola de Engenharia, Guimarães, Portugal (2019), September 25-27, pp. 829-838. ISBN: 978989-54496-2-0. http://hdl.handle.net/11563/139675

[19] Petzel, M. and Heilmeyer, F. Reduce Reuse Recycle. Architecture as Resource. German Pavillion, Venice $13^{\text {th }}$ International Architecture Exibition, Hatje Cantz (2012).

[20] Lembo, F. Isolare dall'esterno. Teoria, tecniche e manutenzione. Volume I Teoria. Edizioni C.E.L.I., Faenza, Italia (1990).

[21] Lembo, F. And Marino F.P.R. Ipotesi di ricostruzione del sistema delle coperture dell'anaktoron di Torre di Satriano. In: M. Osanna \& M. Vullo (Eds.): Segni del potere Oggetti di lusso dal Mediterraneo nell'Appennino lucano di età arcaica, Osanna Edizioni s.r.l., Venosa (PZ), Italia (2013) pp.75-82, ISBN: 9788881674015. http://hdl.handle.net/ $\underline{11563 / 61523}$ 